\title{
UDC 625.122-047.58
}

\author{
V. D. PETRENKO ${ }^{1}$, I. O. SVIATKO ${ }^{2 *}$ \\ ${ }^{1}$ Dep. «Tunnels, Bases and Foundations», Dnipropetrovsk National University of Railway Transport named \\ after Academician V. Lazaryan, Lazaryan St., 2, Dnipropetrovsk, Ukraine, 49010, tel. +38 (050) 7085069 , \\ e-mail petrenko1937@mail.ru, ORCID 0000-0002-5902-6155 \\ $2^{2 *}$ Dep. «Tunnels, Bases and Foundations», Dnipropetrovsk National University of Railway Transport named \\ after Academician V. Lazaryan, Lazaryan St., 2, Dnipropetrovsk, Ukraine, 49010, tel. +38 (056) 37315 79, \\ e-mail i-svjatko@yandex.ua, ORCID 0000-0002-7099-2637
}

\section{SIMULATION OF SUBGRADE EMBANKMENT ON WEAK BASE}

Purpose. This article provides: the question of the sustainability of the subgrade on a weak base is considered in the paper. It is proposed to use the method of jet grouting. Investigation of the possibility of a weak base has an effect on the overall deformation of the subgrade; the identification and optimization of the parameters of subgrade based on studies using numerical simulation. Methodology. The theoretical studies of the stress-strain state of the base and subgrade embankment by modeling in the software package LIRA have been conducted to achieve this goal. Findings. After making the necessary calculations perform building fields of a subsidence, borders cramped thickness, bed's coefficients of Pasternak and Winkler. The diagrams construction of vertical stress performs at any point of load application. Also, using the software system may perform peer review subsidence, rolls railroad tracks in natural and consolidated basis. Originality. For weak soils is the most appropriate nonlinear model of the base with the existing areas of both elastic and limit equilibrium, mixed problem of the theory of elasticity and plasticity. Practical value. By increasing the load on the weak base as a result of the second track construction, adds embankment or increasing axial load when changing the rolling stock process of sedimentation and consolidation may continue again. Therefore, one of the feasible and promising options for the design and reconstruction of embankments on weak bases is to strengthen the bases with the help of jet grouting. With the expansion of the railway infrastructure, increasing speed and weight of the rolling stock is necessary to ensure the stability of the subgrade on weak bases. LIRA software package allows you to perform all the necessary calculations for the selection of a proper way of strengthening weak bases.

Keywords: soil cement; stress-deformed state; finite element method; subgrade; weak base

\section{Introduction}

The new technologies that allow working on strengthening soil quality and reliability are appeared in the bundle of knowledge and experience of native scientists. One of the leading-edge technologies is jet grouting, which allows implementing various constructions enhancement the soil base. The paper presents the main parameters of the numerical analysis of the foundations of the subgrade base using amplification-based jet technology.

When choosing a method of strengthening soil it should be based on its technological and purpose of application. The soil cementation is a penetration and filling of cavities in the soil by means of solution for injection under some pressure. In this regard it is necessary to thoroughly consider the following factors: the lack of damage which inflicted by high pressure building, located near the zone of cementation, if they are available; possibility of squeezing cement at considerable speeds of groundwater or the presence of cavities in the soil and the degree of strength solution for injection.

The jet grouting method includes works on improving soil quality by energy liquid jet for destruction, mixing and replacement of the original natural soil cement slurry, followed by the formation of strong soil cement. It is the formation of cylindrical piles by means of soil's destruction of cement's jets by pressure $200 \quad \ldots 400 \mathrm{~kg} / \mathrm{cm}^{2}$ $(20 \ldots 40 \mathrm{MPa})$, emerging from monitor's nozzle with diameter $\varnothing 2 \ldots 3 \mathrm{~mm}$, attached to the drilling equipment to further mixing and filling of soil with cement.

\section{Purpose}

The aim of this work is to study the impact of a weak base on general deformation of subgrade. 
Another goal is to identify and optimize parameters subgrade through research by numerical simulation.

\section{Methodology}

The theoretical research of the stress-strain state of the roadbed's base and embankment by simulation software LIRA was conducted to reach this goal. The finite element method is among the most contemporary and efficient methods for calculating structures of various purposes, which allows combining two tasks of geomechanics problems: deformation and limit state. The program complex LIRA is a program of numerical simulation processes which occur in soils during the influence of different pressures and also allows exploring the process of deformation and zones development of limiting condition of the soil. During the simulation may be received a complete picture of the stress-strain state of the investigated area, and the importance of breaking load, precipitation, etc.

The follows can be determined by using the software system:

- subsidence of soil and pile base with a given load and engineering-geological conditions;

- limit compressed thickness in accordance with existing regulations;

- the difference subsidence and rolls of existing buildings including those which projected;

- coefficients of the bed soil base according to soil models of Winkler and Pasternak [5,7].

Winkler model is the simplest model that has gained widespread use. This model is based on the fact that the draft stamp proportional loading, deformation and elastic enough after unloading disappear. The only mechanical parameter is the coefficient of bed.

Elastic subsidence of surface under the stamp $D$ under pressure $p$ according Winkler model is defined as

$$
S=P / C
$$

where $C$ - coefficient of subgrade reaction.

The Pasternak's model is used for research deformation of subgrade crest outside of the load transmitted from the rolling stock.
Elastic subsidence of surface around the stamp $D$ under pressure $p$ according Pasternak model is defined as

$$
S=\frac{D_{p}}{D \cdot C_{1}+4 \sqrt{C_{1} C_{2}}+8 \frac{C_{2}}{D}} e^{-\sqrt{\frac{C_{1}}{C_{2}} r}}
$$

where $C_{1}$ - ratio compression, $\mathrm{kgs} / \mathrm{cm}^{3} ; C_{2}$ - offset coefficient, $\mathrm{kgs} / \mathrm{cm} ; r$ - distance from the center of stamp to point out of stamp definition subsidence, $\mathrm{cm}$.

\section{Review of recent research sources and publications}

The problem addressed in many publications. Numerical modeling, particularly in the software LIRA is described in a lot of works [4, 6]. Payment schemes of most commonly used pile bases' models are given in investigation [2]. The problem solutions of subgrade strengthening are devoted at the work $[3,9,7,10]$.

\section{Findings}

Calculation of the roadbed on the weak basis based on the solution of the plane problem of elasticity, but the body of the embankment stability calculations and their slopes are performed by the classical theory of limit equilibrium. In these methods is not taken into account that the occurrence of plastic zones occurs long before the limiting condition in the body of the embankment and soils weak base. In these areas accumulate residual strain that caused vibro dynamic impact load and excessive moisture soils. In weak bases can be slow viscous and plastic flow of soil, aimed at slopes of subgrade, which can cause dangerous shear and expansion joints and cracks.

Thus, for weak soil the most appropriate is nonlinear bases model considering of existing areas as elastic and limit equilibrium that is mixed problem of elasticity and plasticity.

To obtain reliable results, it is necessary to follow those recommendations: to determine deformation and strength characteristics of soils that make up the body of embankments and foundations with sufficient accuracy; define the parameters of the rolling load distribution; establish dimensions of cross-section given its boundaries loose soil with a weak base. Payment schemes that 
are used in full to more accurately show the stressstrain state of the roadbed than the schemes adapted to the axis of symmetry.

Under the influence of load in a weak base appears significant horizontal tension because border calculation scheme (prohibition of horizontal displacement) should be placed as farthest from the place application of the load. Also there are prohibited horizontal movement of the left and right boundaries and vertical movement of the lower nodes of boundary. Splitting cross-section is performed with increasing density of finite element mesh in areas where the expected increase of stresses and displacements values.

The values of loads from rolling stock in the calculation scheme adopted according to the experimentally obtained values. The values of vertical deformation in the event of plastic zones in the soil depend on the nature of the loading. In the absence of plastic deformation load of rolling stock may take one step.

When using the finite element method, the determining soil characteristics and embankment foundations upon this depends largely on the stress-strain state of the real subgrade plays an important role.

In the design scheme of layers of soil are taken according to the results of geological surveys.

Estimated parameters used in the numerical simulation should be taken from Table 1 .

Table 1

Estimated parameters used in the numerical simulation

\begin{tabular}{|c|c|c|c|c|c|}
\hline № & Type of element & Material & $\begin{array}{l}\text { The elastic modulus E, } \\
\mathrm{kN} / \mathrm{m}^{2}\end{array}$ & $\begin{array}{c}\text { Density, } \\
\mathrm{kN} / \mathrm{m}^{3}\end{array}$ & Poisson's ratio \\
\hline 1 & Rail & Metal & $2,06 \times 10^{8}$ & 77,085 & 0,3 \\
\hline 2 & Sleeper & Ferroconcrete & $3,247 \times 10^{8}$ & 24,525 & 0,2 \\
\hline 3 & Ballast & Ballast Stone & 100000 & 22 & 0,2 \\
\hline 4 & $\begin{array}{l}\text { The body of em- } \\
\text { hankments }\end{array}$ & Loam & 25000 & 19 & 0,3 \\
\hline 5 & Weak base & Saturated loam & 5000 & 19 & 0,3 \\
\hline 6 & $\begin{array}{l}\text { Soil cement pile } \varnothing 750 \\
\mathrm{~mm}\end{array}$ & Soil cement & 115000 & 17,5 & 0,3 \\
\hline
\end{tabular}

So to calculate the embankment on the weak basis is performed on calculation scheme with the size of the real profile, creating finite-element mesh, determination of forces and loads. Also there is performed choose of the design characteristics of the system «embankment-weak base» and simulated process system load rolling stock.

Determination of the total subsidence occurs by layered adding using scheme linear deformation half-space (Boussinesq's task).

The achievements limits cramped thickness $H_{c}$ is controlled of

$$
\sigma_{z p}=k \cdot \sigma_{z g}
$$

by using the coefficient depth of cramped thickness $\mathrm{k}$, which is defined.

After making the necessary calculations perform building fields of a subsidence, borders cramped thickness, bed's coefficients of Pasternak and Winkler. The diagrams construction of vertical stress performs at any point of load application.

Also, using the software system may perform peer review subsidence, rolls railroad tracks in natural and consolidated basis.

\section{Originality and practical value}

There was defined the algorithm of forming design scheme for the calculation of the embankment on the weak basis by finite element method. The method of the selection strength characteristics of soils and calculated parameters for using in numerical modeling is offered in the article. The modeling process of load system by rolling stock was grounded.

Analysis of the stress-strain state of the system «weak base-roadbed» allows you to see the basic 
patterns of soil and take the necessary steps for strengthening of soil-cement elements.

\section{Conclusions}

Based on the above, in the condition of the growth rate of the rolling stock and traffic on Ukrainian railways, the investigations allow using software LIRA for the analysis of roadbed operation of rolling stock in the railway, which is reduced on a weak base.

With increasing the load on the weak basis by building of the second track, adding embankment or increasing axial load when changing the rolling process of settling and consolidation can be continue again. Therefore, one of the viable and future options design and reconstruction of embankments on weak bases are strengthening the base by using jet grouting. Covering soil cement piles allows to provide a short time strengthening roadbed, the ability to quickly enter areas of track in operation and small size of subsidence.

\section{LIST OF REFERENCE LINKS}

1. ДБН В.2.1-10-2009. Зміна № 1. Основи та фундаменти споруд. Основні положення проектування. - Введ. 2011-01-07. - Київ : Мінрегіонбуд України, 2011. - 161 с.

2. Исследование параметров модернизированного земляного полотна / В. Д. Петренко, А. М. М. Алхдур, А. Л. Тютькин, В. В. Ковалевич // Вісн. Дніпропетр. нац. ун-ту залізн. трансп. ім. акад. В. Лазаряна. - Дніпропетровськ, 2012. - Вип. 41. - С. 164-169.

3. Линченко, Ю. П. Моделирование свайного основания здания с применением интегральных элементов / Ю. П. Линченко, А. Е. Шуст // Стрво и техногенная безопасность : сб. науч. тр. / НАПКС. - Симферополь, 2010. - Вып. 33-34. C. $176-182$.

4. Литовченко, П. А. Численное моделирование взаимодействия буроинъекционной сваи с локальным закреплением в грунте и окружающего ее грунтового массива / П. А. Литовченко // Стр-во, материаловедение, машиностроение : сб. науч. тр. / ПГАСА. - Днепропетровск, 2013. - Вып. 69. - С. 322-327

5. Новые возможности системы ГРУНТ для определения параметров жесткости грунтового и свайного оснований / Д. А. Городецкий, В. П. Максименко, Д. В. Медведенко, Е. Б. Стрелец-Стрелецкий // Стр-во, материаловедение, машиностроение : сб. науч. тр. /
ПГАСА. - Днепропетровск, 2013. - Вип. 69. C. $155-160$.

6. Петренко, В. Д. Порівняльний аналіз методів укріплення земляного полотна / В. Д. Петренко, І. О. Святко, Д. О. Ямпольський // Стр-во, материаловедение, машиностроение : сб. науч. тр. / ПГАСА. - Днепропетровск, 2013. - Вип. 69. - С. 369-373.

7. Петренко, В. Д. Порівняльний аналіз розрахункових моделей залізничного земляного полотна / В. Д. Петренко, Д. О. Ямпольський, I. О. Святко // Наука та прогрес трансп. Вісн. Дніпропетр. нац. ун-ту залізн. трансп. - 2013. № 4 (46). - C. 56-62. doi: 10.15802/stp2013/16619.

8. Правила розрахунків залізничної колії на міцність і стійкість : ЦП-0117 : затв. наказом Укрзалізниці від 13.12.2004 р. № 960-Ц3. Київ : ЦП УЗ, 2004. - 69 с.

9. Разработка вариантов армирования земляного полотна в сложных инженерно-геологических условиях / В. Д. Петренко, В. Н. Косяк, В. В. Ковальчук, А. М. М. Алхдур // Стр-во, материаловедение, машиностроение : сб. науч. тр. / ПГАСА. - Днепропетровск, 2011. - Вып. 61. - С. 307-312.

10. Строкова, Л. А. Применение метода конечных элементов в механике грунтов : учеб. пособие / Л. А. Строкова. - Томск : Изд-во Томского политехн. ун-та, 2010. - 143 с.

11. Тютькин, А. Л. Сравнительный анализ конечно-элементных моделей свайного фундамента при взаимодействии с основанием / А. Л. Тютькин, А. В. Гулак // Вісн. Дніпропетр. нац. ун-ту залізн. трансп. ім. акад. В. Лазаряна. - Дніпропетровск, 2010. - Вип. 32. C. $122-126$.

12. Roanes-Lozano, E. The Geometry of Railway Geometric Overthrow Revisited Using Computer Algebra Methods / E. Roanes-Lozano // Mathematics in Computer Science. - 2013. - Vol. 7. Iss. 4. - P. 473-485. doi: 10.1007/s11786-0130164-7.

13. Simi, H. Building Simulation Tools for Retrofitting Residential Structures / H. Simi, Amherst // Energy Engineering. - 2012. - Vol. 109. - Iss. 3. - P. 53-74.

14. Wang, J. Measures and Mechanism of Reinforcement of Soft Subgrade of High Speed Railway in Operation / J. Wang, L C. Yang // Applied Mechanics and Materials. - 2013. - Vol. 353-356. - P. 866-872. doi:10.4028/www.scientific.net/amm.353-356.866. 


\title{
В. Д. ПЕТРЕНКО ${ }^{1}$, И. О. СВЯТКО ${ }^{2 *}$
}

\author{
${ }^{1}$ Каф. «Тоннели, основания и фундаменты», Днепропетровский национальный университет железнодорожного \\ транспорта имени академика В. Лазаряна, ул. Лазаряна, 2, Днепропетровск, Украина, 49010, тел. +38 (050) 7085069 , \\ эл. почта petrenko1937@mail.ru, ORCID 0000-0002-5902-6155 \\ ${ }^{2 *}$ Каф. «Тоннели, основания и фундаменты», Днепропетровский национальный университет железнодорожного \\ транспорта имени академика В.Лазаряна, ул. Лазаряна, 2, Днепропетровск, Украина, 49010, тел. +38 (056) 3731579 , \\ эл. почта i-svjatko@yandex.ua, ORCID 0000-0002-7099-2637
}

\section{МОДЕЛИРОВАНИЕ НАСЫПИ ЗЕМЛЯНОГО ПОЛОТНА НА СЛАБОМ ОСНОВАНИИ}

Цель. В статье предусматривается: 1) рассмотрение вопроса обеспечения устойчивости земляного полотна на слабом основании с использованием метода струйной цементации; 2) исследование возможности воздействия слабого основания на общие деформации земляного полотна; 3) выявление и оптимизация параметров земляного полотна на основе исследований с помощью численного моделирования. Методика. Для реализации указанных целей были проведены теоретические исследования напряженнодеформированного состояния основания и насыпи земляного полотна путем моделирования в программном комплексе ЛИРА. Результаты. Для расчета насыпи на слабом основании выполнено: формирование расчетной схемы с размерами реального профиля, создание конечно-элементной сетки, определение сил и нагрузок. Также произведен выбор расчетных характеристик системы «насыпь-слабое основание» и смоделирован процесс нагрузки системы подвижным составом. После осуществления всех необходимых расчетов выполнено построение полей осадок, границ сжимаемой толщи, коэффициентов постели Пастернака и Винклера. Осуществлено построение эпюр вертикальных напряжений в любой точке приложения нагрузки. Также с помощью программного комплекса выполнена экспертная оценка осадок, кренов железнодорожного полотна на естественном и укрепленном основаниях. Научная новизна. Доказано, что для слабых грунтов наиболее целесообразной является нелинейная модель основания с учетом существующих областей как упругого, так и предельного равновесия, то есть смешанная задача теории упругости и пластичности. Практическая значимость. При увеличении нагрузки на слабое основание в результате строительства второго пути, досыпки насыпи или увеличения осевой нагрузки при изменении подвижного состава процесс оседания и консолидации может продолжиться вновь. Поэтому одним из целесообразных и перспективных вариантов проектирования и реконструкции насыпей на слабых основаниях является укрепление основания с помощью струйной цементации. При расширении железнодорожной инфраструктуры, увеличении скоростей движения и веса подвижного состава необходимо обеспечить устойчивость земляного полотна на слабых основаниях. Программный комплекс ЛИРА позволяет выполнить все необходимые расчеты для подбора оптимального способа укрепления слабых оснований.

Ключевые слова: грунтоцемент; напряженно-деформируемое состояние; метод конечных элементов; земляное полотно; слабое основание

\section{В. Д. ПЕТРЕНКО ${ }^{1}$, І. О. СВЯТКО $2^{*}$}

\begin{abstract}
${ }^{1}$ Каф. «Тунелі, основи та фундаменти», Дніпропетровський національний університет залізничного транспорту імені академіка В. Лазаряна, вул. Лазаряна, 2, Дніпропетровськ, Україна, 49010, тел. +38 (050) 7085069 , ел. пошта petrenko1937@mail.ru, ORCID 0000-0002-5902-6155

${ }^{2 *}$ Каф. «Тунелі, основи та фундаменти», Дніпропетровський національний університет залізничного транспорту імені академіка В.Лазаряна, вул. Лазаряна, 2, Дніпропетровськ, Україна, 49010, тел. +38 (056) 3731579 , ел. пошта i-svjatko@yandex.ua, ORCID 0000-0002-7099-2637
\end{abstract}

\section{МОДЕЛЮВАННЯ НАСИПУ ЗЕМЛЯНОГО ПОЛОТНА НА СЛАБКІЙ ОСНОВІ}

Мета. В статті передбачено: 1) розгляд питання забезпечення стійкості земляного полотна на слабкій основі з використанням методу струменевої цементації; 2) дослідження можливості впливу слабкої основи на загальні деформації земляного полотна; 3) виявлення та оптимізація параметрів земляного полотна на основі 
досліджень за допомогою чисельного моделювання. Методика. Для реалізації зазначеної мети були проведені теоретичні дослідження напружено-деформованого стану основи та насипу земляного полотна шляхом моделювання у програмному комплексі ЛІРА. Результати. Для розрахунку насипу на слабкій основі виконано: формування розрахункової схеми з розмірами реального профілю, створення скінченно-елементної сітки, визначення сил і навантажень. Також проведено вибір розрахункових характеристик системи «насипслабка основа» та змодульовано процес навантаження системи рухомим складом. Після здійснення всіх необхідних розрахунків виконано побудування полів осідань, меж стиснутої товщі, коефіцієнтів постелі Пастернака і Вінклера. Здійснено побудову епюр вертикальних напружень у будь-якій точці прикладення навантаження. Також за допомогою програмного комплексу виконано експертну оцінку осідань, кренів залізничного полотна на природній та зміцненій основах. Наукова новизна. Для слабких грунтів найбільш доцільною $є$ нелінійна модель основи з урахуванням існуючих областей як пружної, так і граничної рівноваги, тобто змішана задача теорії пружності та пластичності. Практична значимість. При збільшенні навантаження на слабку основу в результаті будівництва другої колії, досипання насипу або збільшення осьового навантаження при зміні рухомого складу процес осідання і консолідації може продовжитись знов. Тому одним із доцільних й перспективних варіантів проектування та реконструкції насипів на слабких основах $\epsilon$ укріплення основи за допомогою струминної цементації. При розширенні залізничної інфраструктури, збільшенні швидкостей руху та ваги рухомого складу необхідно забезпечити стійкість земляного полотна на слабких основах. Програмний комплекс ЛІРА дозволяє виконати всі необхідні розрахунки для підбору оптимального способу укріплення слабких основ.

Ключові слова: грунтоцемент; напружено-деформований стан; метод скінченних елементів; земляне полотно; слабка основа

\section{REFERENCES}

1. DBN V.2.1-10-2009. Zmina №1. Osnovy ta fundamenty sporud. Osnovni polozhennia proektuvannia [State Standart V. 2.1-10-2009. Amendment No. 1. Bases and foundations of buildings. General design]. Kyiv, Minrehionbud Ukrainy Publ., 2011. 161 p.

2. Petrenko V.D., Alkhdur A.M.M., Tyutkin A.L., Kovalevich V.V. Issledovaniye parametrov modernizirovannogo zemlyanogo polotna [Research of parameters of the modernized subgrade]. Visnyk Dnipropetrovskoho natsionalnoho universytetu zaliznychnoho transportu imeni akademika V. Lazariana [Bulletin of Dnipropetrovsk National University of Railway Transport named after Academician V. Lazaryan], 2012, issue 41, pp. 164-169.

3. Linchenko Yu.P., Shust A.Ye. Modelirovaniye svaynogo osnovaniya zdaniya s primeneniyem integralnykh elementov [Modeling of pile foundation of a building with integrated elements]. Sbornik nauchnykh trudov Natsionalnoy akademii prirodookhrannogo i kurortnogo stroitelstva. Stroitelstvo i tekhnogennaya bezopasnost [Proc. of the National Academy of environmental and resort construction. Construction and industrial safety], 2010, issue 33-34, pp. 176-182.

4. Litovchenko P.A. Chislennoye modelirovaniye vzaimodeystviya buroinektsionnoy svai s lokalnym zakrepleniyem $\mathrm{v}$ grunte i okruzhayushchego yeye gruntovogo massiva [Numerical simulation of the interaction of drill injection piles with local anchoring in the soil and the surrounding soil mass]. Stroitelstvo, materialovedeniye, mashinostroeniye [The Construction, Materials science and Engineering], 2013, issue 69, pp. 322-327.

5. Gorodetskiy D.A., Maksimenko V.P., Medvedenko D.V., Strelets-Streletskiy Ye.B. Novyye vozmozhnosti sistemy GRUNT dlya opredeleniya parametrov zhestkosti gruntovogo i svaynogo osnovaniy [New features of a GRUNT system for determining the stiffness parameters of the soil and pile foundation]. Stroitelstvo, materialovedeniye, mashinostroeniye [The Construction, Materials Science and Engineering], 2013, issue 69, pp. 155-160.

6. Petrenko V.D., Sviatko I.O., Yampolskyi D.O. Porivnialnyi analiz metodiv ukriplennia zemlianoho polotna [Comparative analysis of methods of strengthening the subgrade]. Stroitelstvo, materialovedeniye, mashinostroeniye [The construction, Materials science and Engineering], 2013, issue 69, pp. 369-373.

7. Petrenko V.D., Yampolskyi D.O., Sviatko I.O. Porivnialnyi analiz rozrakhunkovykh modelei zaliznychnoho zemlianoho polotna [Comparative analysis of calculation models of railway subgrade]. Nauka ta prohres transportu. Visnyk Dnipropetrovskoho natsionalnoho universytetu zaliznychnoho transportu - Science and Transport Progress. Bulletin of Dnipropetrovsk National University of Railway Transport, 2013, no. 4 (46), pp. 56-62. doi: 10.15802/stp2013/16619. 
8. Pravyla rozrakhunkiv zaliznychnoi kolii na mitsnist $i$ stiikist : TsP-0117 [The rules of calculations of railway track on the strength and stability: TsP-0117]. Kyiv, TsP UZ Publ., 2004. 69 p.

9. Petrenko V.D., Kosyak V.N., Kovalchuk V.V., Alkhdur A.M.M. Razrabotka variantov armirovaniya zemlyanogo polotna $\mathrm{v}$ slozhnykh inzhenerno-geologicheskikh usloviyakh [The development of options for subgrade reinforcement in difficult engineering-geological conditions]. Stroitelstvo, materialovedeniye, mashinostroeniye [The Construction, Materials Science and Engineering], 2011, issue 61, pp. 307-312.

10. Strokova L.A. Primeneniye metoda konechnykh elementov v mekhanike gruntov [Application of the finite element method in soil mechanics]. Tomsk, Izdatelstvo Tomskogo politekhnicheskogo universiteta Publ., 2010. $143 \mathrm{p}$.

11. Tyutkin A.L., Hulak A.V. Sravnitelnyy analiz konechno-elementnykh modeley svaynogo fundamenta pri vzaimodeystvii s osnovaniyem [Comparative analysis of finite element models of pile foundation in cooperation with the base]. Visnyk Dnipropetrovskoho natsionalnoho universytetu zaliznychnoho transportu imeni akademika $V$. Lazariana [Bulletin of Dnipropetrovsk National University of Railway Transport named after Academician V. Lazaryan], 2010, issue 32, pp. 122-126.

12. Roanes-Lozano E. The Geometry of Railway Geometric Overthrow Revisited Using Computer Algebra Methods. Mathematics in Computer Science, 2013, vol. 7, issue 4, pp. 473-485. doi: 10.1007/s11786-013-0164-7.

13. Simi H., Amherst. Building Simulation Tools for Retrofitting Residential Structures. Energy Engineering, 2012, vol. 109, issue 3, pp. 53-74.

14. Wang J., Yang L.C. Measures and Mechanism of Reinforcement of Soft Subgrade of High Speed Railway in Operation. Applied Mechanics and Materials, 2013, vol. 353-356, pp. 866-872. doi:10.4028/www.scientific.net/amm.353-356.866.

PhD in Sc. V. S. Andreev (Tech.); Prof. V. L. Sedin, D. Sc. (Tech.) recommended this article to be published

Received: June 08, 2015

Accepted: Aug. 14, 2015 